\title{
Description of appendages from three marine trachyleberidid species (Ostracoda, Crustacea) from Japan
}

\author{
GENGO TANAKA ${ }^{1, *} \&$ KOJI SETO ${ }^{2}$ \\ ${ }^{1}$ Gunma Museum of Natural History, Tomioka, Gunma 370-2345, Japan \\ ${ }^{2}$ Research Center for Coastal Lagoon Environments, Shimane University, Matsue 690-8504, Japan \\ *Corresponding author (e-mail: tanaka@gmnh.pref.gunma.jp)
}

\begin{abstract}
Three living trachyleberidid ostracod species, Acanthocythereis munechikai Ishizaki, Actinocythereis kisarazuensis Yajima and Hirsutocythere hanaii Ishizaki, were discovered in the Tsushima Straits, c. $120 \mathrm{~km}$ east of Tsushima Island (north Island), N 34 $46^{\prime} \mathrm{E} 130^{\circ} 46^{\prime}$ at a depth of $116 \mathrm{~m}$. This is the first description of complete appendages for these genera. J. Micropalaeontol. 29(1): 5-16, May 2010.
\end{abstract}

KEYWORDS: Acanthocythereis munechikai, Actinocythereis kisarazuensis, Hirsutocythere hanaii, Ostracoda, Trachyleberididae

\section{INTRODUCTION}

Ostracods are small bivalved crustaceans (average adult length of $c .1 \mathrm{~mm}$ ) abundantly found in the fossil record from the Ordovician onwards, as well as in a wide range of aquatic environments. The ostracod Family Trachyleberididae was defined by Sylvester-Bradley (1948) with a fossil record from the Cretaceous onwards (Whatley et al., 1993). To date, 57 trachyleberidid species belonging to 22 genera have been described from Japan (Table 1). The Trachyleberididae has been classified into several subfamilies, such as Trachyleberidinae, Buntoniinae and Phacorhabdotinae. The heavily calcified trachyleberidid ostracod carapaces are found abundantly in Cenozoic sediments around Japan. Many Recent trachyleberidid species have a fossil record from the Neogene onwards. However, only four Trachyleberidid species with appendages have been recorded from Japan, T. scabrocuneata (Brady, 1880) (for illustrated appendages, see Harding \& Sylvester-Bradley, 1953; Okubo, 1979), T. ikeyai (Tanaka, 2008), Bicornucythere bisanensis (Okubo, 1975) and Pistocythereis bradyi (Ishizaki, 1968) (for description of the appendages, see Okubo, 1979). The aim of this study is to describe three Japanese trachyleberidid ostracod species with their appendages.

\section{MATERIAL AND METHODS}

Surface sediments of the Tsushima Strait (St. 13) were collected using the Smith-McIntyre grab sampler during cruises by $T R V$ Toyoshio-maru (November $15-20,1999), c .120 \mathrm{~km}$ east of Tsushima Island (north Island), N $34^{\circ} 46^{\prime}$ E $130^{\circ} 46^{\prime}$ at a depth of $116 \mathrm{~m}$. A total of 36 ostracod species were identified in the sample (see Tanaka, 2008). To extract additional specimens with appendages, a spare sample of St. 13 was examined under a binocular microscope. As a result, seven cytheroidean ostracod species with appendages were recovered from $132 \mathrm{~g}$ of dry sediment: Acanthocythereis munechikai Ishizaki, 1981; Actinocythereis kisarazuensis Yajima, 1978; Bradleya japonica Benson, 1972; Cytheropteron uchioi Hanai, 1957; Hirsutocythere hanaii Ishizaki, 1981; Munseyella oborozukiyo Yajima, 1982; and Trachyleberis ikeyai Tanaka, 2008. Of these, three trachyleberidid species, A. munechikai, A. kisarazuensis, and H. hanaii, were analysed further. Dried specimens were softened in a $10 \%$ sodium tripolyphosphate solution. Dissections of appendages were made in glycerine under a Nikon SMZ-U stereoscopic microscope, mounted in Neo-Shigaral on glass slides, and covered. The appendages and valves were drawn with a camera lucida attachment and an Olympus BX41 stereoscopic microscope. Other carapaces were mounted on stubs and coated with gold using a JEOL ion sputter (JFC-1100), prior to being viewed using a JEOL JSM-6100 scanning electron microscope. All illustrated specimens are deposited in the University Museum, University of Tokyo (UMUT RA).

\section{SYSTEMATIC DESCRIPTIONS}

Family Trachyleberididae Sylvester-Bradley, 1948 Genus Acanthocythereis Howe, 1963

Acanthocythereis munechikai Ishizaki, 1981

(P1. 1; Fig. 1)

1981 Acanthocythereis munechikai Ishizaki: 45, 46, pl. 9, figs 1, 2a-c, 3; pl. 14, fig. 8; pl. 15, figs $3 \& 4$.

1985 Acanthocythereis munechikai Ishizaki; Wang \& Zhao: pl. 7, fig. 8.

1988 Acanthocythereis munechikai Ishizaki; Paik \& Lee: pl. 2, fig. 16.

1988 Acanthocythereis munechikai Ishizaki; Zhao \& Wang: pl. 2, fig. 14.

1988 Acanthocythereis munechikai Ishizaki; Wang et al.: 246, 247, pl. 18, figs 1-3.

1989 Trachyleberis? zhoushanensis Liu: 154, pl. 168, figs 9 \& 10. 1992 Acanthocythereis munechikai Ishizaki; Ikeya \& Suzuki: pl. 1, fig. 3 .

1992 Acanthocythereis munechikai Ishizaki; Lee \& Paik: pl. 4, fig. 8.

1998 Acanthocythereis munechikai Ishizaki; Irizuki et al.: fig. 6 (6).

2001 Acanthocythereis munechikai Ishizaki; Irizuki et al.: fig. 7 (14).

2001 Acanthocythereis munechikai Ishizaki; Nakao et al.: fig. 11 (13).

2007 Acanthocythereis munechikai Ishizaki; Hou \& Gou: 454, pl. 172 , figs 15 \& 16 . 


\begin{tabular}{ll}
\hline Family & Genus \\
\hline $\begin{array}{l}\text { Trachyleberididae } \\
\text { Sylvester-Bradley, } 1948\end{array}$ & Abrocythereis Gou, 1983 (in Gou et al., 1983)
\end{tabular}

Acanthocythereis Howe, 1963

Actinocythereis Puri, 1953 (Puri, 1953a in this reference)

Alocopocythere Siddiqui, 1971

Ambocythere Van Den Bold, 1957

Ambtonia Malz, 1982

Amphileberis Guan, 1978 (in Guan et al., 1978) Austoralimoosella Hartmann, 1978

Bicornucythere Schornikov \& Shaitarov, 1979 Buntonia Howe, 1935 (in Howe \& Chambers, 1935)

Campylocythereis Omatsola, 1971

Celtia Neale, 1973

Falsobuntonia Malz, 1982

Hirsutocythere Howe, 1951

Isocythereis Triebel, 1940

Murrayina Puri, 1954

Neocytheretta Van Morkhoven, 1963

Pacambocythere Malz, 1982

Pistocythereis Gou, 1983 (in Gou et al., 1983)

Robertsonites Swain, 1963

Sinoleberis Hu, 1979

Trachyleberis Brady, 1898
Species

Abrocythereis ryukyuensis Malz \& Tabuki, 1988

Abrocythereis yajimae Nohara, 1987

Acanthocythereis ashiyaensis Yamaguchi, 2007 (in Yamaguchi \& Kamiya, 2007)

Acanthocythereis fujinaensis Tanaka, 2002 (in Tanaka et al., 2002)

Acanthocythereis izumoensis Tanaka, 2002 (in Tanaka et al., 2002)

Acanthocythereis japonica Irizuki \& Yamada, 2004 (in Irizuki et al., 2004)

Acanthocythereis munechikai Ishizaki, 1981

Acanthocythereis mutsuensis Ishizaki, 1971

Acanthocythereis? niitsumai (Ishizaki, 1971)

Acanthocythereis quadrata Irizuki \& Yamada, 2004 (in Irizuki et al., 2004)

Acanthocythereis tsurugasakensis Tabuki, 1986

Actinocythereis kisarazuensis Yajima, 1978

Alocopocythere? ishizakii Nohara, 1987

Ambocythere uchinaensis Nohara, 1987

Ambtonia? matsubarai Yamaguchi, 2006

Ambtonia obai (Ishizaki, 1971)

Ambtonia shimanensis Tanaka, 2002 (in Tanaka et al., 2002)

Ambtonia takayasui Tanaka, 2002 (in Tanaka et al., 2002)

Amphileberis nipponica (Yajima, 1978)

Australimoosella tomokoae (Ishizaki, 1968)

Australimoosella hanaii Yajima, 1992

Bicornucythere bisanensis (Okubo, 1975)

Buntonia hanaii Yajima, 1978

Buntonia parascorta Ishizaki, 1983

Buntonia scorta Ishizaki, 1983

Buntonia u-carinata Ishizaki, 1983

Campylocythereis? ukifune Yajima, 1982

Celtia japonica Ishizaki, 1981

Falsobuntonia hayamii (Tabuki, 1986)

Falsobuntonia? waitaensis Yamaguchi, 2007 (in Yamaguchi \& Kamiya, 2007)

Hirsutocythere? akatsukiborensis Yajima, 1992

Hirsutocythere hanaii Ishizaki, 1981

Hirsutocythere? nozokiensis (Ishizaki, 1963)

Isocythereis? roochuensis Nohara, 1987

Murrayina japonica Tabuki, 1986

Neocytheretta? iwasakii (Nohara, 1987)

Pacambocythere ishizakii Nohara, 1987

Pacambocythere japonica (Ishizaki, 1968)

Pistocythereis bradyformis (Ishizaki, 1968)

Pistocyhereis bradyi (Ishizaki, 1968)

Robertsonites hanaii Tabuki, 1986

Robertsonites irizukii Yamada, 2003

Robertsonites japonicus (Ishizaki, 1966)

Robertsonites leptoreticulata Yamada, 2003

Robertsonites reticulatus Irizuki \& Yamada, 2004 (in Irizuki et al., 2004)

Robertsonites reticuliformus (Ishizaki, 1966)

Robertsonites tsugaruana Tabuki, 1986

Robertsonites yatsukanus Tanaka, 2002 (in Tanaka et al., 2002)

Sinoleberis tosaensis (Ishizaki, 1968)

Trachyleberis? funatsuensis Yamaguchi, 2006

Trachyleberis ikeyai Tanaka, 2008

Trachyleberis inouei Yamaguchi, Nagao \& Kamiya, 2006

Trachyleberis ishizakii Yasuhara et al., 2002

Trachyleberis mizunamiensis Yajima, 1992

Trachyleberis scabrocuneata (Brady, 1880)

Trachyleberis shukunohorensis Yajima, 1992

Trachyleberis straba Frydl, 1982

Table 1. Trachyleberidid ostracods described from Japan. 


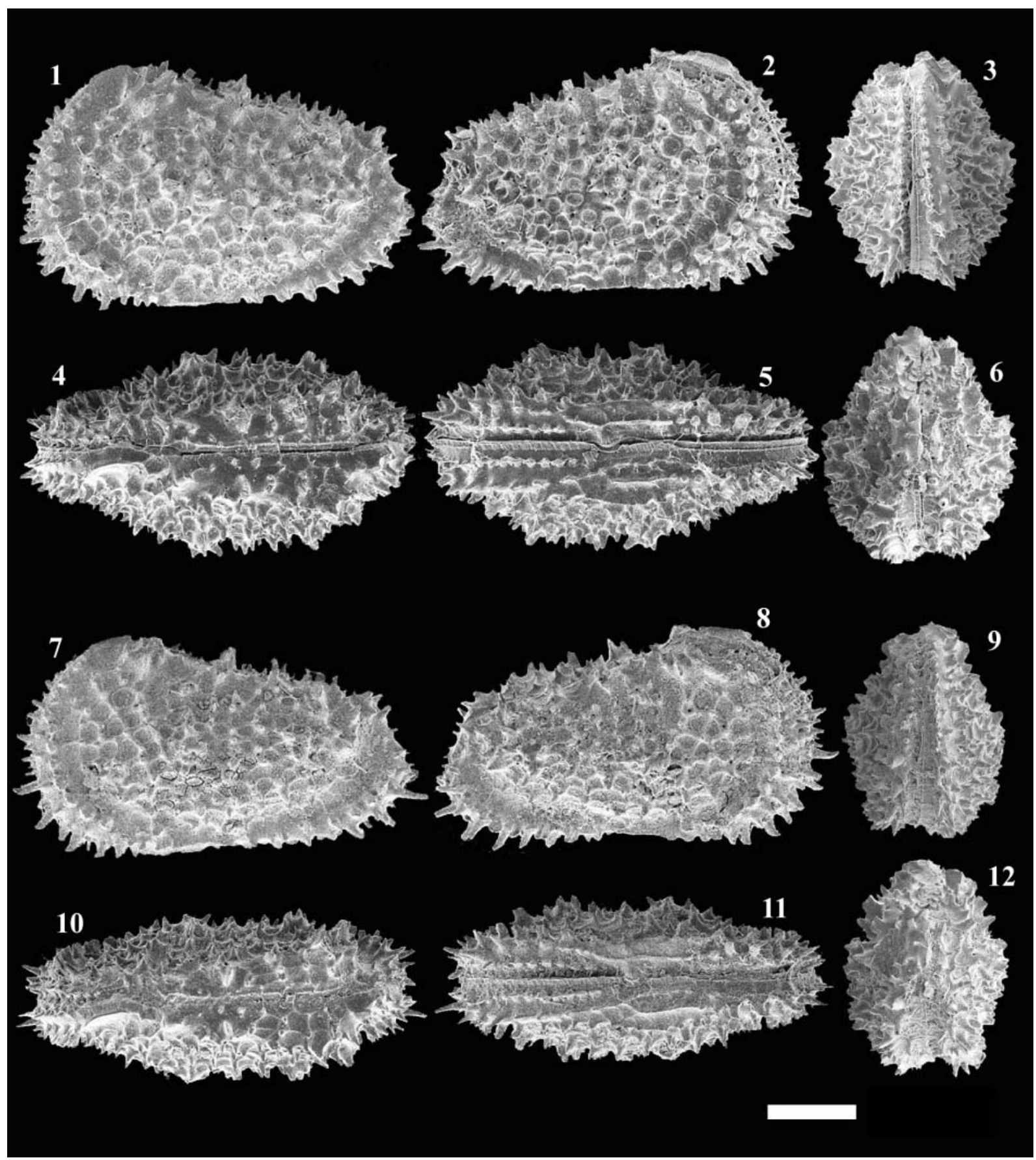

Explanation of Plate 1.

figs 1-12. Scanning electron photomicrographs of the carapaces of Acanthocythereis munechikai Ishizaki, 1981, female (1-6; UMUT RA30558) and male (7-12; UMUT RA30559) from the Tsushima Strait, southwestern Japan: 1, 7, left lateral view; 2, 8, right lateral view; 3, 9, anterior view; 4, $\mathbf{1 0}$, dorsal view; 5, 11, ventral view; $\mathbf{6 , 1 2}$, posterior view. Scale bar $100 \mu \mathrm{m}$.

Description. Valve sub-quadrate in lateral view (P1. 1, figs 1, 2, 7, 8). Anterior margin evenly rounded with conical spines, especially anteroventrally; dorsal margin straight, sloping toward posterior with several conical spines; posterior margin truncated near middle, slope nearly straight above, convex below with several long conical spines; ventral margin concave in middle. Strong sexual dimorphism; male elongated in lateral view; female carapace inflated laterally in anterior, dorsal and posterior views. Eye tubercle absent. Surface ornamented by polygonal reticulations with conical and clavate spines. Row of prominent clavate spines at base of anterodorsal corner running nearly parallel to anterior margin. In dorsal and ventral views, lateral outline fusiform-shaped (P1. 1, figs 4, 5, 10, 11). In anterior and posterior views, carapace subovate, broadest near mid-height (Pl. 1, figs 3, 6, 9, 12). Marginal pore canals straight and/or curved with median swellings; 53 anterior, 21 ventral and 


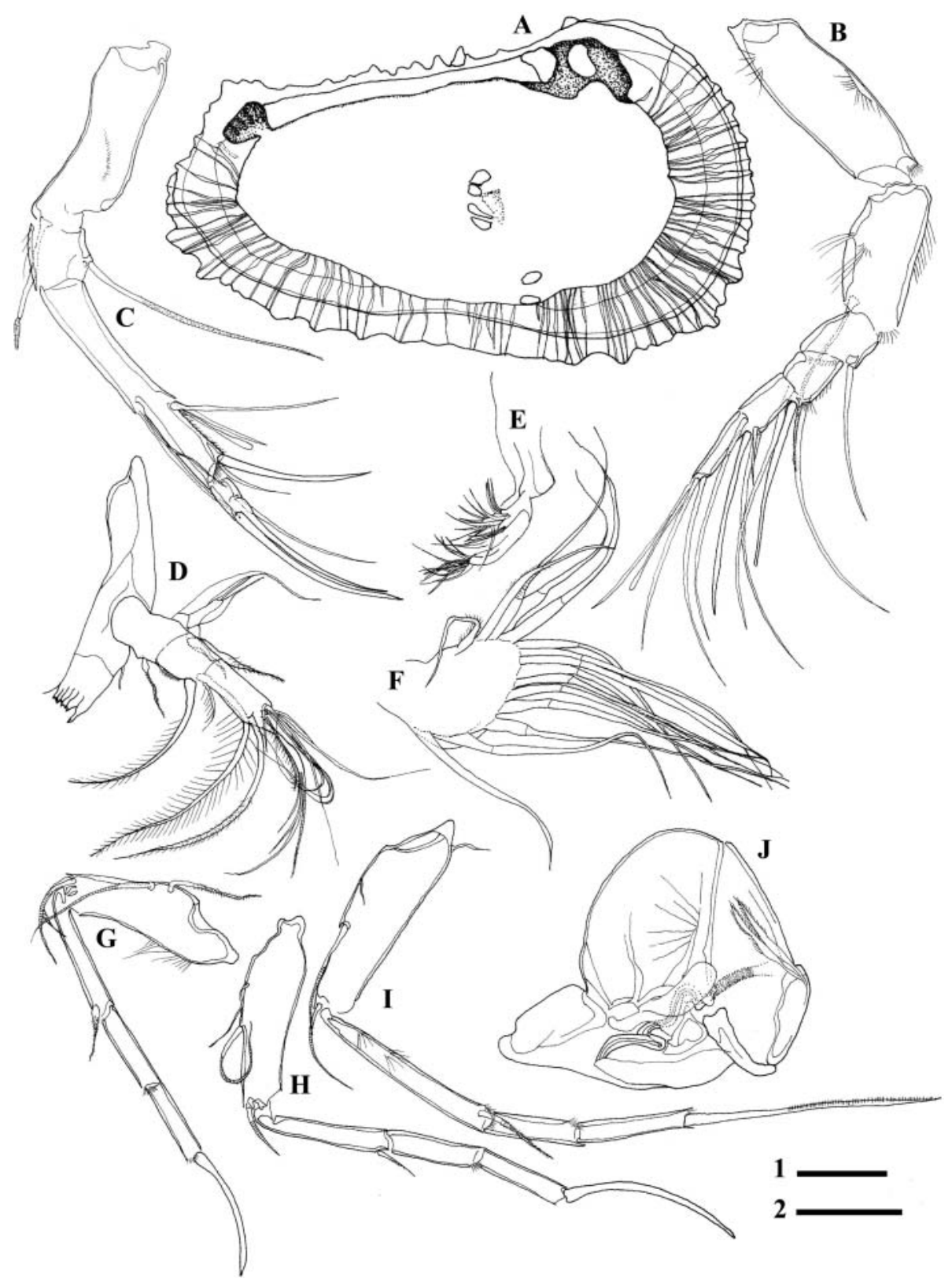

Fig. 1. The valve and the male soft parts of Acanthocythereis munechikai Ishizaki, 1981: A, male left valve (UMUT RA30560); B-J, soft parts of the male (UMUT RA30561) - B, antennule, C, antenna, D, mandible, E, distal segment of maxillula, F, branchial plate of maxillula, G, first thoracic leg, H, second thoracic leg, I, third thoracic leg, J, copulatory organ. Scale 1, $100 \mu \mathrm{m}$ for A; scale 2, $100 \mu \mathrm{m}$ for B-J.

17 posterior pore canals (Fig. 1A). Duplicature developed. Hinge holamphidont: left valve, anterior element with auxiliary tooth in large elongate socket; anteromedian element a smooth tooth, posteromedian element a bar; posterior element an elongated socket. Four elliptical adductor scars in vertical row (upper two semi-circular, others elliptical). Two elliptical mandibular scars. Small anteromedian depression in front of adductor scars.

Antennule (Fig. 1B): six articulated segments. Length ratio between distal segments 85: 60: 25: 17: 20: 30. Exoskeletons developed, especially segments $2-5$. First segment with long setules on middle anterior margin and posterior proximal margin, small bunch of short setules anterior distal end. Second segment with plumose seta posterior distal end, and middle posterior margin; long setules proximal half of anterior margin; small bunch of short setules anterior distal end. Third segment with seta anterior distal end, row of small bunches of short setules on distal end. Fourth segment with long seta and relatively stout seta on anterior distal end, numerous short setules anterior margin, long seta centre. Fifth segment ledge anterior distal end with 4 setae: 2 long setae, 1 relatively stout seta and 1 short seta. Sixth segment distal end with 3 long setae, 1 relatively short seta with club-like structure at distal end.

Antenna (Fig. 1C): four articulated segments. Length ratio between distal segments 40: 12: 51: 8. Exoskeletons developed, especially broad in third and fourth segments. First segment 
with row of numerous short setules outer lateral side. Second segment with short 2-segmented (actually 3 segments, but first and second fused), exopodite with several long setules at base and long plumose seta posterior distal end. Third segment with paired setae anterior margin, 1 relatively long seta and 2 short setae, one of which shows paddle-like shape at the distal end, numerous short setules one-third from distal end, and pair of unequal setae (outer seta longer and stouter) and row of small bunches of short setules distal end. Fourth segment with stout clawlike seta anterior margin distal end and 2 setae (claw-like stout seta and relatively fine seta) ledge posterior margin.

Mandible (Fig. 1D): five segmented. Length ratio between 2 protopodite segments and 3 endopodite segments 51: 14: 10: 15: 16. Basal segment (coxa, first segment of protopodite) with about 6 teeth, 1 seta anterior distal margin. Second segment of protopodite (basis) with exopodite consisting of 5 setae, and 2 plumose setae posterior distal margin. First segment of endopodite with 2 long feather-like setae, 1 short comb-like seta, and 1 simple seta ventral distal end, plumose seta dorsal distal end. Second segment of endopodite with a pair of unequal setae (long plumose seta and short comb-like seta) posterior distal margin, and 7 long fine setae anterior distal end. Third segment of endopodite bearing 3 simple setae and 1 plumose seta.

Maxillula (Figs 1E, F): extremely thin branchial plate (exopodite) with 16 plumose setae (Fig. 1F). Basal podomere bearing palp and 3 masticatory processes (Fig. 1E). Palp 2-segmented. Proximal segment with 3 setae anterior distal end. Distal segment with 1 stout seta and 7 setae on distal end and near inner masticatory lobe, respectively. Outer masticatory process with 7 setae on distal end. Each of the middle and inner masticatory processes with 4 setae.

Thoracic legs (Figs 1G-I): all three legs 4-segmented and similar in shape. Length ratio between distal segments 60: 55: 38 : 35 in first thoracic leg, 67: 59: 40: 38 in second thoracic leg, 40: 43: 20: 23 in third thoracic leg. Distal margin of each segment sometimes covered with many short setules. Exoskeletons developed on both margins of each segments. First segment with two setae anterior margin and 1 or 2 plumose seta(e) anterior distal end. Second segment bearing plumose seta on anterior distal end. Fourth segment bearing large terminal claw.

Copulatory organ of male (Fig. 1J): basal capsule rounded. Exoskeleton developed along anterior margin. Subtriangular supporting lobe (distal lobe) developed on distal end of basal capsule. Ductus ejaculatorius well developed and twisted at one-half from distal end. One long linguiform clasping apparatus posterior side of ductus ejaculatorius.

Remarks. The genus Acanthocythereis was defined by Howe (1963) from the middle Eocene Cook Mountain Formation in Louisiana, USA. It was distinguished from Trachyleberis Brady, 1898 in having web-like reticulations between spines and in lacking the muscle scar node. The present species differs from Acanthocythereis sp. 1 reported from the Pacific coast of southwest Japan, by Zhou (1995), in its caudal process more protruded ventrally. The specimens figured by Zheng (1994) as A. munechikai have a different posterior outline and surface ornamentation compared to those described by Ishizaki (1981). The fossil specimen figured by Irizuki et al. (2001) has more prominent reticulation.
Genus Actinocythereis Puri, 1953a Actinocythereis kisarazuensis Yajima, 1978

$$
\text { (P1. 2, Fig. 2) }
$$

1978 Actinocythereis kisarazuensis Yajima: 399, 400, pl. 49, figs 3a, b; text-fig. 9; fig. 1 .

1985 Actinocythereis kisarazuensis Yajima; Wang \& Zhao: pl. 7, fig. 10.

1988 Actinocythereis kisarazuensis Yajima; Zhao \& Wang: pl. 2, fig. 15.

1988 Actinocythereis kisarazuensis Yajima; Wang et al.: 247, pl. 18 , figs $6 \& 7$.

1989 Actinocythereis spinosa Liu: 155, pl. 169, fig. 5.

1992 Actinocythereis kisarazuensis Yajima; Ikeya \& Suzuki: pl. 1, fig. 5 .

2007 Actinocythereis kisarazuensis Yajima; Hou \& Gou: 451, 452, pl. 179, fig. 10; pl. 204, fig. 8.

2008 Actinocythereis kisarazuensis Yajima; Tanaka: fig. 2q.

Description. Valve sub-quadrate in lateral view (Pl. 2, figs 1, 2, 7, 8). Anterior margin evenly rounded with clavate spines, especially anteroventrally; dorsal margin straight, sloping toward posterior with several clavate spines; posterior margin truncated near middle, slope nearly straight above, convex below with several long conical spines; ventral margin concave in middle. Weak sexual dimorphism; male slightly elongated in lateral view; female carapace slightly inflated laterally in anterior view. Eye tubercle present. Surface ornamented by several clavate spines. Row of 7 clavate spines runs nearly parallel to anterior margin. Lateral outline fusiform-shaped in dorsal and ventral views, anterior end more pointed than posterior ( $\mathrm{Pl}$. 2, figs $4,5,10,11)$. Carapace subhexagonal in anterior and posterior views, broadest near mid-height ( $\mathrm{Pl}$. 2, figs 3, 6, 9, 12). Marginal pore canals straight and/or curved; 59 anterior, 14 ventral, and 16 posterior pore canals (Fig. 2A). Duplicature developed. Hinge holamphidont: right valve anterior element with stepped tooth; anteromedian element a large elongate socket, posteromedian element a crenulated socket; posterior element a round tooth. Four elliptical adductor scars in vertical row. Two elliptical mandibular scars. A deep anteromedian depression in front of adductor scars, corresponding to the external subcentral tubercle.

Antennule (Fig. 2B): six articulated segments. Length ratio between distal segments 62: 40: 15: 15: 14: 21. Exoskeletons developed, especially segments $2-5$. First segment with row of short setules outer lateral side, two rows of short setules near distal end, and long setules on posterior proximal margin. Second segment with plumose seta on posterior distal end, long setules near proximal anterior margin; small bunch of short setules on anterior distal end. Third segment with seta on anterior distal end and row of small bunches of short setules on distal end. Fourth segment with long seta and stout seta anterior distal end with numerous short setules anterior margin, long seta centre. Fifth segment ledge anterior distal end with 4 setae: 2 long setae, 1 relatively stout seta, and 1 short seta. Sixth segment distal end with 3 long setae and 1 relatively short seta with club-like structure at the distal end.

Antenna (Fig. 2C): four articulated segments. Length ratio between distal segments 30: 11: 35: 6. Exoskeletons developed, 


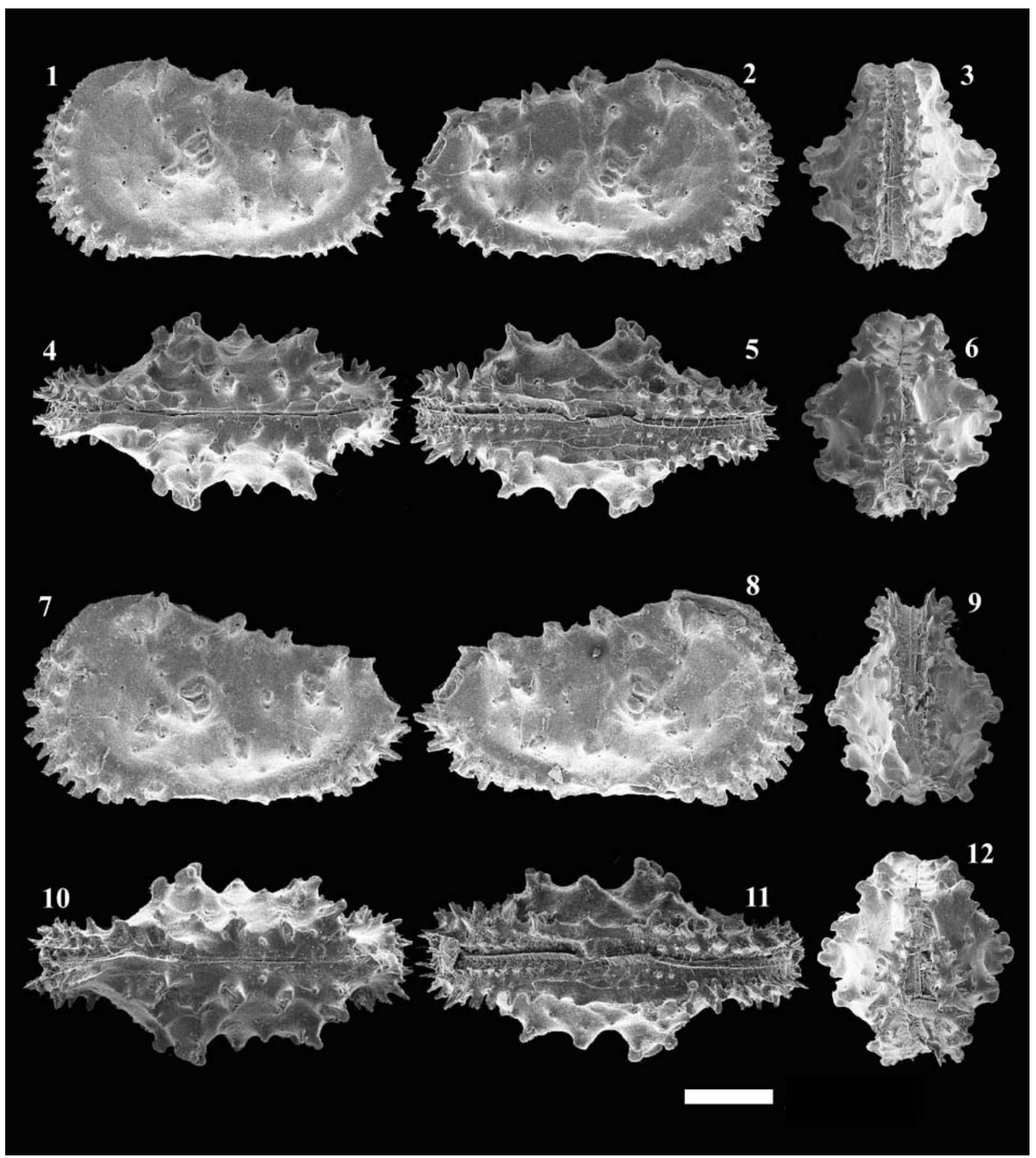

Explanation of Plate 2.

figs 1-12. Scanning electron photomicrographs of the carapaces of Actinocythereis kisarazuensis Yajima, 1978, female (1-6; UMUT RA30562) and male (7-12; UMUT RA30563) from the Tsushima Strait, southwestern Japan: 1, 7, left lateral view; 2, 8, right lateral view; 3, 9, anterior view; 4, $\mathbf{1 0}$, dorsal view; $\mathbf{5}, \mathbf{1 1}$, ventral view; $\mathbf{6 , 1 2}$, posterior view. Scale bar $100 \mu \mathrm{m}$.

especially in broad third and fourth segments. First segment with two unequal rows of numerous short setules outer lateral side. Second segment with short 2-segmented (actually 3 segments, but first and second fused) exopodite, 2 long setules at base of exopodite and a long plumose seta posterior distal end, numerous setules outer lateral side. Third segment with a pair of setae ( 1 short plumose seta and 1 long simple seta) along anterior margin, posterior margin with one relatively long seta and 2 short setae, one of which shows paddle-like shape at distal end, a pair of unequal setae (outer seta longer and stouter) and a row of small bunch of short setules on distal end. Fourth segment with stout claw-like seta along anterior margin distal end and 2 setae (claw-like stout seta and relatively fine seta) on ledge on posterior margin. 


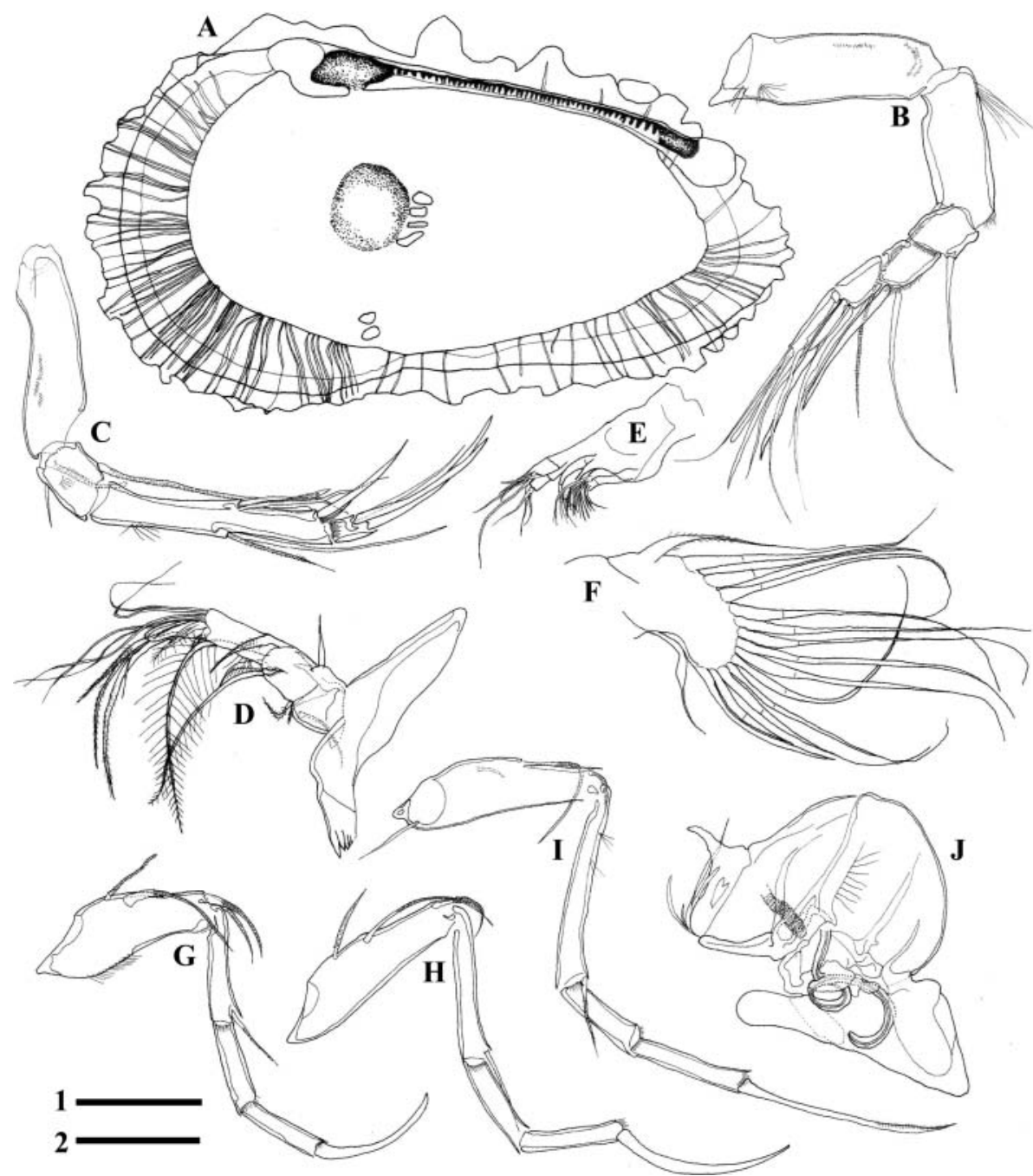

Fig. 2. The valve and the male soft parts of Actinocythereis kisarazuensis Yajima, 1978: A, male right valve (UMUT RA30564); B-J, soft parts of the male (UMUT RA30565) - B, antennule, C, antenna, D, mandible, E, distal segment of maxillula, F, branchial plate of maxillula, G, first thoracic leg, H, second thoracic leg, I, third thoracic leg, J, copulatory organ. Scale 1, $100 \mu \mathrm{m}$ for A; scale 2, $100 \mu \mathrm{m}$ for B-J.

Mandible (Fig. 2D): five segmented. Length ratio between 2 protopodite segments and 3 endopodite segments 80: 14: 17: 21 : 19. Basal segment (coxa, first segment of protopodite) with six teeth. Second segment of protopodite (basis) with exopodite consisting of five setae, and 2 plumose setae posterior distal margin. First segment of endopodite with 2 long feather-like setae, 1 short comb-like seta, and 1 short plumose seta ventral distal end, stout plumose seta dorsal distal end. Second segment of endopodite with a pair of unequal plumose setae posterior distal margin, and 5 long fine setae and 2 short setae anterior distal end. Third segment of endopodite bearing 3 plumose setae and 1 simple seta.

Maxillula (Figs 2E, F): extremely thin branchial plate (exopodite) with 15 plumose setae (Fig. 2F). Basal podomere bearing palp and 3 masticatory processes. Palp 2-segmented. Proximal segment with 3 setae anterior distal end. Distal segment with 1 plumose seta and 4 setae distal end. Outer masticatory process with 7 setae distal end. Each of the middle and inner masticatory processes with 4 setae.
Thoracic legs (Figs 2G-I). All three legs 4-segmented and similar in shape. Length ratio between distal segments 46: $32: 25$ : 24 in first thoracic leg, 52: 42: 27: 31 in second thoracic leg, and 61: 55: 25: 35 in third thoracic leg. Distal margin of each segment sometimes covered with many short setules. Exoskeletons developed on both margins of each segments. First segment with two setae anterior margin, 1 or 2 plumose seta(e) anterior distal end. Second segment bearing plumose seta on anterior distal end. Fourth segment bearing large terminal claw.

Copulatory organ of male (Fig. 4J): basal capsule rounded. Exoskeleton developed along anterior margin. Subtriangular supporting lobe (distal lobe) developed distal end basal capsule. Ductus ejaculatorius well developed and coiled at one-half from distal end. One linguiform clasping apparatus posterior side of ductus ejaculatorius.

Remarks. Puri (1953a) distinguished Actinocythereis from Trachyleberis by its three distinct rows of spines on the carapace. The spines of A. kisarazuensis do not show such an arrangement, 


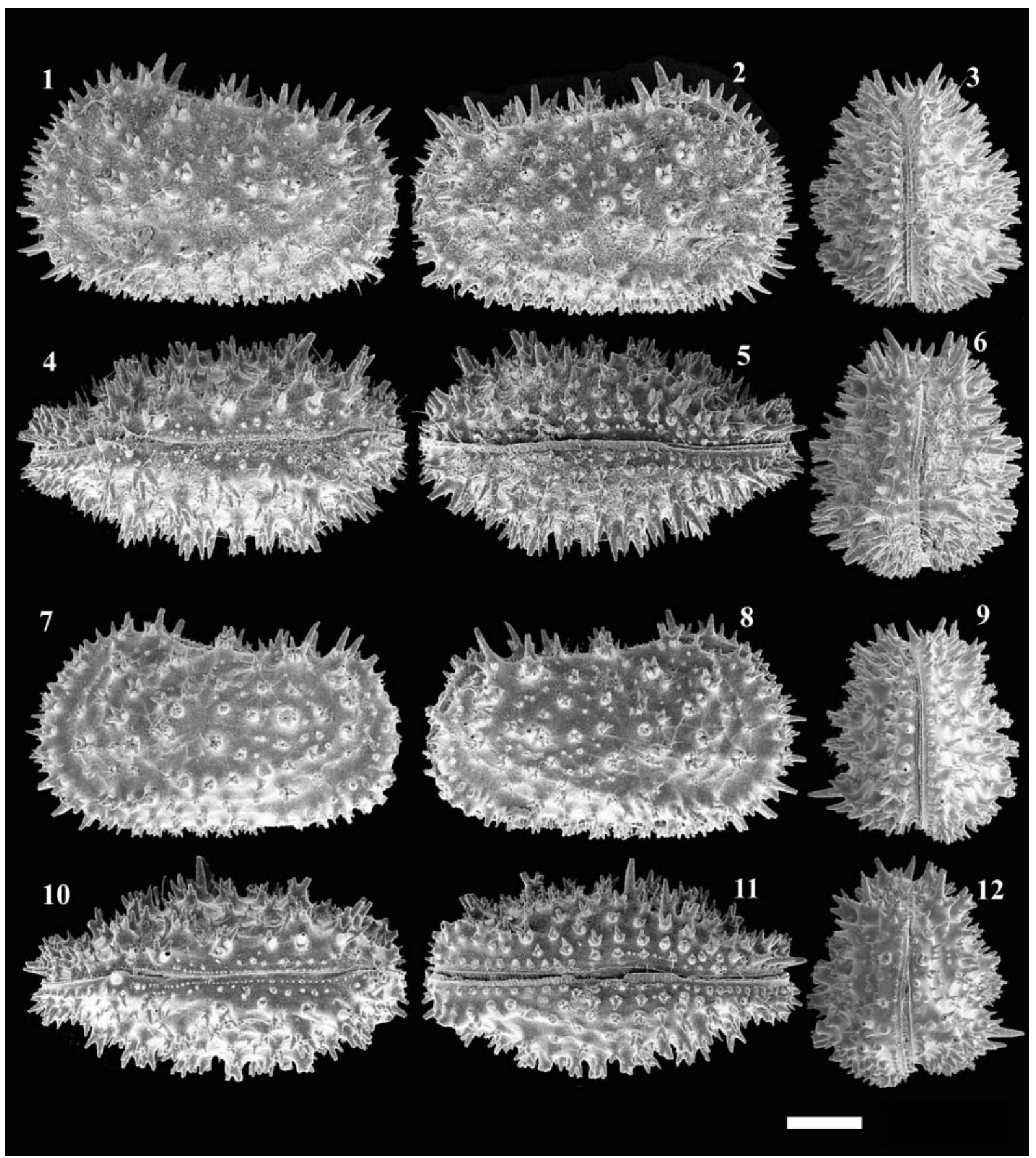

Explanation of Plate 3.

figs 1-12. Scanning electron photomicrographs of the carapaces of Hirsutocythere hanaii Ishizaki, 1981, female (1-6; UMUT RA30566) and male (7-12; UMUT RA30567) from the Tsushima Strait, southwestern Japan: 1, 7, left lateral view; 2, 8, right lateral view; 3, 9, anterior view; 4, 10, dorsal view; 5, 11, ventral view; 6, 12, posterior view. Scale bar $100 \mu \mathrm{m}$.

although two horizontal rows of spines are recognized in the species (Yajima, 1978). However, other morphological characters of A. kisarazuensis are closely assigned to the genus Actinocythereis, as Hanai et al. (1977) mentioned. The present species is similar to Actinocythereis scutigera (Brady) figured in Zhao et al. (1985; pl. 19, fig. 12), but the node pattern on the dorsal part of the carapace is different. This species differs from $A . ? \mathrm{sp}$.
E, which was reported from the Recent sediment of the Ulleung Basin, Korea by Cheong et al. (1986), in its more protruded caudal process.

Genus Hirsutocythere Howe, 1951 Hirsutocythere hanaii Ishizaki, 1981 (P1. 3, Fig. 3) 


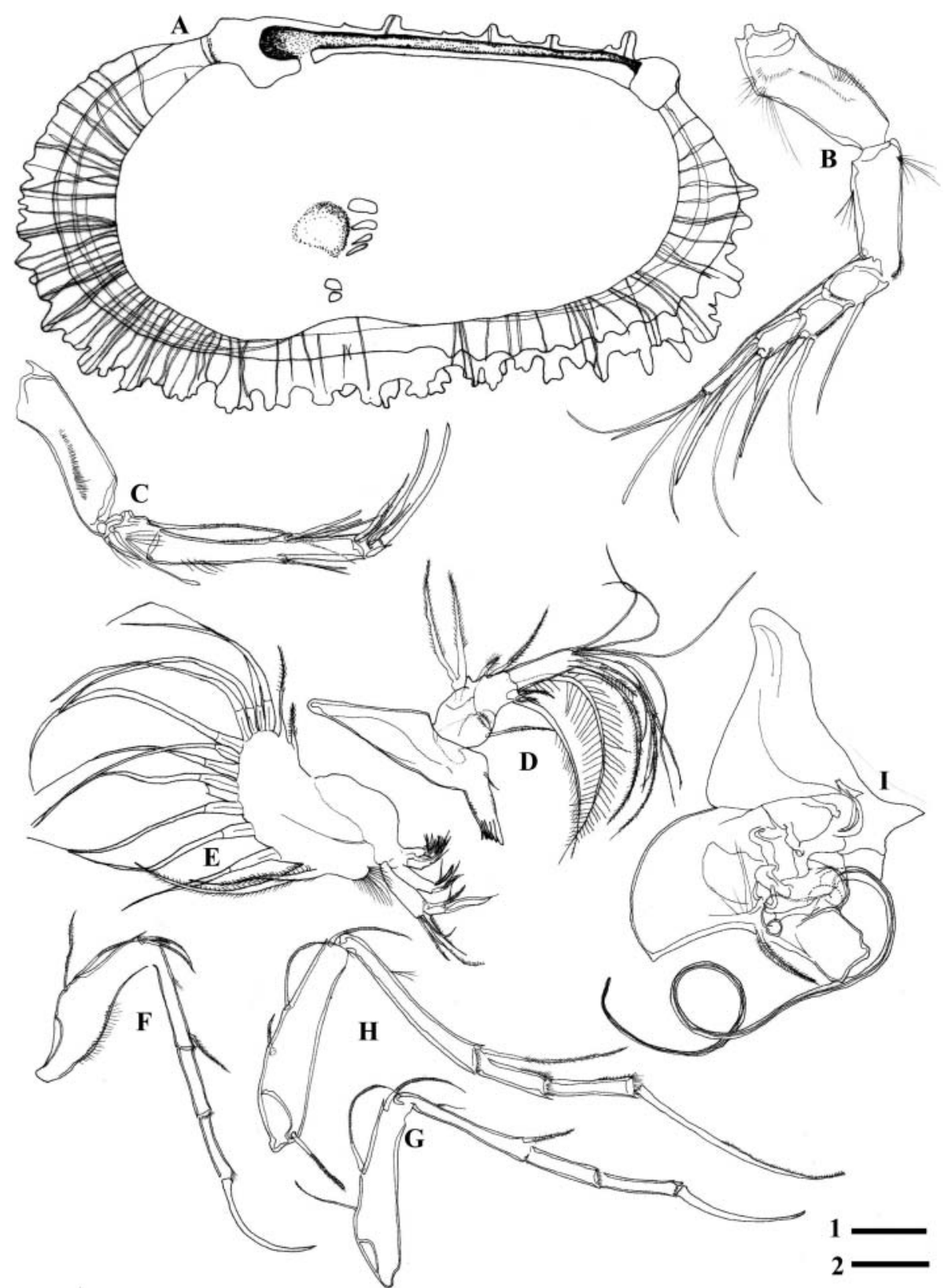

Fig. 3. The valve and the male soft parts of Hirsutocythere hanaii Ishizaki, 1981: A, male right valve (UMUT RA30568); B-J, soft parts of the male (UMUT RA30569) - B, antennule, C, antenna, D, mandible, E, maxillula; F, first thoracic leg; G, second thoracic leg; H, third thoracic leg; I, copulatory organ. Scale $1,100 \mu \mathrm{m}$ for A; scale $2,100 \mu \mathrm{m}$ for B-J.

1981 Hirsutocythere? hanaii Ishizaki: 46, 47, pl. 9, figs 4a, b, 5a, b, 6a, b, 7; pl. 15, fig. 6 .

1985 Hirsutocythere? hanaii Ishizaki; Wang \& Zhao: pl. 7, fig. 12.

1988 Hirsutocythere? hanaii Ishizaki; Wang et al:: 247, 248, pl. 18 , figs $10-13$.

1988 Hirsutocythere hanaii Ishizaki; Paik \& Lee: pl. 2, fig. 17. 1988 Hirsutocythere? nozokiensis Ishizaki; Yajima: pl. 2, fig. 16. 1988 Hirsutocythere? hanaii Ishizaki; Ruan \& Hao: 360, 361, pl. 66 , figs $12 \& 13$.

1989 Hirsutocythere? hanaii Ishizaki; Liu: 158, 159, pl. 171, figs $7 \& 11$.
1992 Hirsutocythere? hanaii Ishizaki; Ikeya \& Suzuki: pl. 5, fig. 5.

1992 Hirsutocythere hanaii Ishizaki; Lee \& Paik: pl. 4, fig. 7. 1996 Hirsutocythere? hanaii Ishizaki; Kamiya et al.: pl. 4, figs 9 $\& 10$.

1996 Hirsutocythere? hanaii Ishizaki; Ozawa: pl. 5, fig. 6. 1998 Hirsutocythere? hanaii Ishizaki; Irizuki et al.: fig. 6 (7). 2001 Hirsutocythere? hanaii Ishizaki; Irizuki et al.: fig. 7 (15). 2001 Hirsutocythere? hanaii Ishizaki; Nakao et al:: fig. 11 (13). 2007 Hirsutocythere? hanaii Ishizaki; Hou \& Gou: 456, pl. 179, figs 17-21; pl. 182, figs 13 \& 14 .

2008 Hirsutocythere? hanaii Ishizaki; Tanaka: fig. 2r. 
Description. Valve sub-quadrate in lateral view (P1. 3, figs 1, 2, 7, $8)$. Anterior and posterior margins evenly rounded with conical spines, spines especially large and long ventrally; dorsal margin straight, sloping toward posterior with several long conical spines; ventral margin convex. Male slightly elongated in lateral view; female carapace slightly inflated laterally in anterior, dorsal and posterior views. Prominent long conical spine ventrolateral side male right valve. Eye tubercle absent. Surface ornamented by many prickly spines, some clustered. Lateral outline fusiform-shaped in dorsal and ventral views, anterior end more pointed than posterior ( $\mathrm{Pl}$. 3, figs 4, 5, 10, 11). Carapace subovate in anterior and posterior views, broadest near mid-height (Pl. 3, figs 3, 6, 9, 12). Marginal pore canals straight and/or curved numbering 49 anterior, 20 ventral and 17 posterior (Fig. 3A). Duplicature developed. Hinge holamphidont: right valve anterior element with stepped tooth; anteromedian element a large elongate socket, posteromedian element a long socket; posterior element a round tooth. Four elliptical adductor scars in vertical row. Two elliptical mandibular scars. Deep anteromedian depression anterior of adductor scars.

Antennule (Fig. 3B): six articulated segments. Length ratio between distal segments 23: 16: 6: 5: 6: 9. Exoskeletons developed, especially in segments 2-5. First segment with three clusters of setules outer lateral side and row of long setules posterior proximal margin. Second segment with plumose seta posterior distal end, long setules near proximal end anterior and posterior margins; small bunch of short setules anterior distal end. Third segment with seta anterior distal end and row of small bunches of short setules distal end. Fourth segment with long seta and stout seta with comb-like structure anterior distal end, numerous short setules on anterior margin, long seta centre. Fifth segment with 4 setae: 2 long setae, 1 stout seta with comb-like structure, and 1 short seta ledge anterior distal end. Sixth segment with 3 long setae and 1 short seta distal end.

Antenna (Fig. 3C): Four articulated segments. Length ratio between distal segments 58: 19: 72: 6. Exoskeletons developed, especially in broad third and fourth segments. First segment with a row of numerous setules outer lateral side. Second segment with short 2-segmented (actually 3 segments, but first and second fused) exopodite, a long setule at the base of the exopodite, two long setules on anterior proximal end, and 6 long setules outer lateral side, long plumose seta posterior distal end. Third segment with a pair of setae anterior margin, 1 relatively long seta and 2 stout setae distal end, numerous short setules middle, and a pair of unequal setae (outer seta longer and stouter with comb-like structure) on distal end. Fourth segment with stout claw-like seta along anterior margin distal end and 2 setae (claw-like stout seta and relatively fine seta) ledge posterior margin.

Mandible (Fig. 3D): five segmented. Length ratio between 2 protopodite segments and 3 endopodite segments 41: 9: 8: 11: 12. Basal segment (coxa, first segment of protopodite) with 6 teeth, and 1 seta anterior distal margin. Second segment of protopodite (basis) with exopodite consisting of three setae, and 2 plumose setae posterior distal margin. First segment of endopodite with 2 long feather-like setae and two plumose setae ventral distal end, a plumose seta dorsal distal end. Second segment of endopodite with a pair of unequal plumose setae on posterior distal margin, and 7 long fine setae on anterior distal end. Third segment of endopodite bearing 1 simple seta and 2 plumose setae.

Maxillula (Figs 3E): extremely thin branchial plate (exopodite) with 16 plumose setae and many long setules ledge anterior distal margin (Fig. 3E). Basal podomere bearing palp and 3 masticatory processes (Fig. 3E). Palp 2-segmented. Proximal segment with 3 setae anterior distal end. Distal segment with 1 stout plumose seta, 3 simple setae and 1 stout comb-like seta distal end. Outer masticatory process with 6 setae distal end. Each of the middle and inner masticatory processes with 4 setae.

Thoracic legs (Figs 3F-H): all 3 legs 4-segmented and similar in shape. Length ratio between distal segments 56: 36: 22: 23 in first thoracic leg, 32: 23: 12: 14 in second thoracic leg, 32: 30: 13: 15 in third thoracic leg. Distal margin of each segment sometimes covered with many short setules. Exoskeletons developed on both margins of each segments. First segment with two plumose setae anterior margin, and 1 or 2 plumose seta(e) anterior distal end. Second segment with plumose seta anterior distal end. Forth segment bearing large terminal claw.

Copulatory organ of male (Fig. 3I): basal capsule semilunar. Exoskeleton developed along anterior margin. Subtriangular supporting lobe (distal lobe) developed on distal end of basal capsule. Long ductus ejaculatorius with single coil. One large quadrangular clasping apparatus posterior side of ductus ejaculatorius.

Remarks. This species has been unreliably included in the genus Hirsutocythere by many authors since Ishizaki (1981) described it. The present species differs from the genotype species Hirsutocythere hornotina Howe, 1951, in its narrow marginal infold area (possibly equal to the vestibule of Scott, 1961). However, the width of the vestibule of a trachyleberidid Ostracoda Alocopocythere kendengensis shows wide variation even in the same species (e.g., Carbonel \& Hoibian, 1988, fig. 7), although the cause of the variation of the vestibule has not yet been clarified. Moreover, the shell outline and its surface ornamentation with long prickly spines are closely similar to $H$. hornotina. The Japanese genus also resembles the genus Echinocythereis Puri (1953b), but differs with its prickly spines and has no concentric arrangement pattern of the spines. Carinocythereis (Ruggieri, 1956) is clearly distinguished from the Japanese genus, with its prominent four longitudinal ridges developed from anterior to posterior of the shell surface. This species resembles Hirsutocythere? akatsukiborensis Yajima, 1992 in carapace outline, but the pattern of surface ornamentation of the carapace is clearly distinct from that of $H$. akatsukiborensis. This species differs from Hirsutocythere? nozokiensis (Ishizaki, 1963 ) in its arrangement of the prickly spines of anteromedian area. The fossil specimens figured by Irizuki et al. (1998, 2001) and Nakao et al. (2001) as Hirsutocythere? hanaii have slightly different shell outlines from Recent ones.

\section{ACKNOWLEGEMENTS}

The authors express sincere thanks to the crew of $T R V$ Toyoshio-maru for collecting and lending sediment samples. Thanks go to Robin Smith (Lake Biwa Museum), Ian Boomer (University of Birmingham) and Rosalie Maddocks (University of Houston) for helpful comments aiding improvement of the paper. The authors are grateful to Elly Brouwers (USGS) and 
John Gregory (PetroStrat Ltd) for reviewing and editing this paper and to Haruyoshi Maeda and Terufumi Ohno (Kyoto University) and Akira Tsukagoshi (Shizuoka University) for use of the facility and relevant references. Finally, thanks to Crimson Interactive Pvt. Ltd for correcting the English.

\section{Manuscript received 20 January 2009 \\ Manuscript accepted 26 January 2010}

\section{REFERENCES}

Benson, R. 1972. The Bradleya problem, with descriptions of two new phychrosperic ostracode genera, Agrenocythere and Poseidonamicus (Ostracoda, Crustacea). Smithsonian Contribution to Paleobiology, 12: $1-138$.

Brady, G.S. 1880. Report on the Ostracoda dredged by H.M.S. Challenger, during the years 1873-1876. Report of scientific result of the Voyage HMS Challenger, Zoology, 1: 1-184.

Brady, G.S. 1898. On new or imperfectly known species of Ostracoda chiefly from New Zealand. Transactions of the Zoological Society of London, 14: 429-452.

Carbonel, P. \& Hoibian, T. 1988. The impact of organic matter on ostracods from an equatorial deltaic area, the Mahakam DeltaSoutheastern Kalimantan. In: Hanai, T., Ikeya, N. \& Ishizaki, K. (Eds), Evolutionary Biology of Ostracoda - Its Fundamentals and Applications. Kodansha, Tokyo, 353-366.

Cheong, H., Lee, E., Paik, K. \& Chang, S. 1986. Recent ostracodes from the southwestern slope of the Ulleung Basin, East Sea, Korea. Journal of the Paleontological Society of Korea, 2: 38-53.

Frydl, P.M. 1982. Holocene ostracods in the southern Boso Peninsula. In: Hanai, T. (Ed.), Studies on Japanese Ostracoda. The University Museum, the University of Tokyo, Bulletin, 20: 64-140.

Gou, Y., Zheng, S. \& Huang, B. 1983. Pliocene ostracode fauna of Leizhou Peninsula and northern Hainan Island, Guangdong Province. Palaeontologia Sinica, 162: 1-117.

Guan, S., Sun, Q., Jiang, Y., Li, L., Zhao, B., Zhang, X., Yang, R. \& Feng, B. 1978. Ostracoda. In: Institute of Geological Sciences, Hubei Province et al. (Eds), Paleontological Atlas of Zhong-nan Area, Part 4, Microfossils. Geological Press, Beijing, 153-325.

Hanai, T. 1957. Studies on the Ostracoda from Japan. III. Subfamilies Cytherurinae G.W. Müller (emend. G. O. Sars 1925) and Cytheropterinae n. subfam. Journal of the Faculty of Science, University of Tokyo, 11: 113-136.

Hanai, T., Ikeya, N., Ishizaki, K., Sekiguchi, Y. \& Yajima, M. 1977. Checklist of Ostracoda from Japan and its adjacent seas. The University Museum, the University of Tokyo Bulletin, 12: 1-119.

Harding, J.P. \& Sylvester-Bradley, P.C. 1953. The ostracod genus Trachyleberis. Bulletin of the British Museum, Natural History, Zoology, 2: 1-15.

Hartmann, G. 1978. Die Ostracoden der Ordnung Podocopida G. W. Müller, 1894 der tropisch-subtropischen Westküste Australiens (zwischen Derby im Norden und Perth im Süden). Mitteilungen aus dem Hamburgischen zoologischen Museum und Institut, 75: 63-219.

Hou, Y. \& Gou, Y. 2007. Fossil Ostracoda of China, vol. 2, Cytheracea and Cytherellidae. Science Press, Beijing, 798pp.

Howe, H.V. 1951. New Tertiary ostracode fauna from Levy County, Florida. Florida State Geological Survey Bulletin, Tallahassee, 34: $1-43$.

Howe, H.V. \& Chambers, J. 1935. Louisiana Jackson Eocene Ostracoda. Louisiana Geological Survey, Geological Bulletin, 5: 1-61.

Howe, R.C. 1963. Type saline Bayou Ostracoda of Louisiana. Louisiana Geological Survey, Geological Bulletin, Baton Rouge, 40: 1-62.

$\mathrm{Hu}, \mathrm{C}$. 1979. Studies on ostracode faunas from the Hengchun Formation, Hengchun Peninsula, southern Taiwan. Petroleum Geology of Taiwan, 16: 59-84.

Ikeya, N. \& Suzuki, C. 1992. Distributional patterns of modern ostracodes off Shimane Peninsula, southwestern Japan Sea. Reports of Faculty of Science, Shizuoka University, 26: 91-137.

Irizuki, T., Ishizaki, K., Takahashi, M. \& Usami, M. 1998. Ostracode faunal changes after the mid-Neogene climatic optimum elucidated in the Middle Miocene Kobana Formation, Central Japan. Paleontological Research, 2: 30-46.

Irizuki, T., Yamaguchi, T., Takahashi, M. \& Yanagisawa, Y. 2001. Miocene temperate Ostracoda from the Tochigi and Fukushima districts, central to northeastern Japan. In: Ikeya, N. (Ed.), 14th International Symposium on Ostracoda, Guidebook of Excursions. The Organising Committee of ISO 2001, Shizuoka, 45-72.

Irizuki, T., Yamada, K., Maruyama, T. \& Ito, H. 2004. Paleoecology and taxonomy of Early Miocene Ostracoda and paleoenvironments of the eastern Setouchi Province, central Japan. Micropalaeontology, 50: $105-147$.

Ishizaki, K. 1963. Japanese Miocene ostracodes from the Sunakosaka Member of the Yatsuo Formation, east of Kanazawa City, Ishikawa Prefecture. Japanese Journal of the Geology and Geography, 34: 19-34.

Ishizaki, K. 1966. Miocene and Pliocene ostracodes from the Sendai area, Japan. Science Reports of the Tohoku University, 2nd Series (Geology), 37: 131-163.

Ishizaki, K. 1968. Ostracodes from Uranouchi Bay, Kochi Prefecture, Japan. Science Reports of the Tohoku University, 2nd Series (Geology), 40: 1-45.

Ishizaki, K. 1971. Ostracodes from Aomori Bay, Aomori Prefecture, northeast Honshu, Japan. Science Reports of the Tohoku University, 2nd Series (Geology), 43: 59-97.

Ishizaki, K. 1981. Ostracoda from the East China Sea. Science Reports of the Tohoku University, 2nd Series (Geology), 51: 37-65.

Ishizaki, K. 1983. Ostracoda from the Pliocene Ananai Formation, Shikoku, Japan. Transactions and Proceedings of the Palaeontological Society Japan, New Series, 131: 135-159.

Kamiya, T., Ozawa, H. \& Kitamura, A. 1996. Paleo-water mass structure during the deposition of middle part of the Omma Formation based on the change of ostracode assemblage. Hokuriku Geology Institute Report, 5: 145-165.

Lee, E. \& Paik, K. 1992. Late Cenozoic ostracod fauna and paleoenviroments of the marine sedimentary strata in the Cheju Island, Korea. Paleontological Society of Korea, Special Publications, 1: 121-160.

Liu, Z. 1989. Ostracoda. In: Research party of marine geology, Ministry of Geology and Mineral Resources and institute of Geology, Chinese Academy of Geological Sciences (Ed.), Cenozoic paleobiota of the continental shelf of the East China Sea (Donghai), paleozoological volume. Geological Publishing House, Beijing, 136-172.

Malz, H. 1982. Plio-/Pleistozäne Buntoniini von SW-Taiwan. Senckenbergiana Lethaea, 63: 377-411.

Malz, H. \& Tabuki, R. 1988. The ostracod genus Abrocythereis (Miocene to Recent) from the Indopacific. Geologica et Palaeontologica, 22: 157-173.

Nakao, Y., Tanaka, G. \& Yamada, S. 2001. Pleistocene and living marine Ostracoda in Shizuoka District, Japan. In: Ikeya, N. (Ed.), 14th International Symposium on Ostracoda, Guidebook of Excursions. The Organising Committee of ISO 2001, Shizuoka, 127-147.

Neale, W.J. 1973. Celtia gen. nov., a new genus of marine Ostracoda (Crustacea) from the Celtic Province and Neogene deposits. Revista Espaňola de Micropaleontología, 5: 435-444.

Nohara, T. 1987. Cenozoic ostracodes of Okinawa-jima. Bulletin of College of Education, University of the Ryukyus, 30: 1-105.

Okubo, I. 1975. Callistocythere pumila Hanai, 1957 and Leguminocythereis bisanensis sp. nov. in the Inland Sea, Japan (Ostracoda). Proceedings of the Japanese Society of Systematic Zoology, 11: 23-31.

Okubo, I. 1979. Six species of marine Ostracoda from the Inland Sea of Seto. Research Bulletin of Shujitsu Women's College and Okayama Shujitsu Junior College, 9: 143-157.

Omatsola, M.E. 1971. Campylocythereis, a new genus of the Campylocytherinae (Ostracoda, Crustacea) and its muscle scar variation. In: Oertli, H.J. (Ed.), Paléoécologie d'Ostracodes Pau 1970. Bulletin du Centre de Recherche Pau-SNPA, Pau, 5: 101-123.

Ozawa, H. 1996. Ostracode fossils from the late Pliocene to early Pleistocene Omma Formation in the Hokuriku district, central Japan. Science Reports of Kanazawa University, 41: 77-115.

Paik, K. \& Lee, E. 1988. Plio-Pleistocene ostracods from the Sogwipo Formation, Cheju Island, Korea. In: Hanai, T., Ikeya, N. \& Ishizaki, 
K. (Eds), Evolutionary Biology of Ostracoda: Its Fundamentals and Applications. Kodansha, Tokyo, 541-556.

Puri, H.S. 1953a. The ostracode genus Trachyleberis and its ally Actinocythereis. American Midland Naturalist, 49: 171-187.

Puri, H.S. 1953b. Contribution to the study of the Miocene of the Florida Panhandle. Florida Geological Survey, Geological Bulletin, 36: 223-345.

Puri, H.S. 1954. Contribution to the study of the Miocene of the Florida Panhandle. Pt. 3, Ostracoda. Florida Geological Survey, Geological Bulletin, 36: 223-345.

Ruan, P. \& Hao, Y. 1988. II. Descriptions of ostracode genera and species. In: Research Party of Marine Geology, Ministry of Geology and Mineral Resources \& Chinese University of Geosciences (Eds), Quaternary Microbiotas in the Okinawa Trough and Their Geological Significance. Geological Publishing House, Beijing, 227-395.

Ruggieri, G. 1956. La suddivisione degli Ostracodi già compresi nel genere Cythereis proposta da Neviani. Atti della Società Italiana di Scienze Naturali, 155: 161-175.

Scott, H.W. 1961. Shell morphology of Ostracoda. In: Moore, R.C. (Ed.), Treatise on Invertebrate Paleontology, Part Q, Arthropoda 3. Geological Society of America \& University of Kansas Press, Colorado, 21-37.

Schornikov, E.I. \& Shaitarov, S.V. 1979. A new genus of ostracods from Far- Eastern Seas. Biologiya, 2: 41-47.

Siddiqui, Q.A. 1971. Early Tertiary Ostracoda of the family Trachyleberididae from West Pakistan. Bulletin of the British Museum (Natural History), Geology, 9: 1-98.

Swain, F.M. 1963. Pleistocene Ostracoda from the Gubik Formation, Arctic coastal plain, Alaska. Journal of Paleontology, 37: 798-834.

Sylvester-Bradley, P.C. 1948. The ostracode genus Cythereis. Journal of Paleontology, 22: 792-797.

Tabuki, R. 1986. Plio-Pleistocene Ostracoda from the Tsugaru Basin, North Honshu, Japan. Bulletin of College of Education, University of the Ryukyus, 29: 27-160.

Tanaka, G. 2008. Recent benthonic ostracod assemblages as indicators of the Tsushima Warm Current in the southwestern Sea of Japan. Hydrobiologia, 598: 271-284.

Tanaka, G., Seto, K., Mukuda, T. \& Nakano, Y. 2002. Middle Miocene ostracods from the Fujina Formation, Shimane Prefecture, Southwest Japan and their paleoenvironmental significance. Paleontological Research, 6: 1-22.

Triebel, E. 1940. Die Ostracoden der deutschen Kreide. Cytherideinae und Cytherinae aus der Unteren Kreide. Senckenbergiana, 22: 160227.

Yajima, M. 1978. Quaternary Ostracoda from Kisarazu near Tokyo. Transactions and Proceedings of the Palaeontological Society of Japan, New Series, 112: 371-409.

Yajima, M. 1982. Late Pleistocene Ostracoda from the Boso Peninsula, Central Japan. In: Hanai, T. (Ed.), Studies on Japanese Ostracoda. The University Museum, the University of Tokyo, Bulletin, 20: $141-227$.
Yajima, M. 1988. Preliminary notes on the Japanese Miocene Ostracoda. In: Hanai, T., Ikeya, N. \& Ishizaki, K. (Eds), Evolutionary Biology of Ostracoda-Its Fundamentals and Applications. Kodansha, Tokyo, 1073-1985.

Yajima, M. 1992. Early Miocene Ostracoda from Mizunami, central Japan. Bulletin of the Mizunami Fossil Museum, 19: 247-267.

Yamada, K. 2003. New ostracod (Crustacea) species of the genus Robertsonites from the Upper Pliocene Kuwae and Sasaoka formations, central and northeast Japan. Journal of Micropalaeontology, 22: 169-181.

Yamaguchi, T. 2006. Eocene ostracodes from the Iojima Group, Nagasaki Prefecture, southwestern Japan. Journal of Paleontology, 80: 902-918.

Yamaguchi, T. \& Kamiya, T. 2007. Oligocene-Miocene ostracode assemblages with the genus Palmoconcha from Japan. Journal of Paleontology, 81: 632-642.

Yamaguchi, T., Nagao, R. \& Kamiya, T. 2006. Paleogene ostracodes from the Kishima Formation, Kishima Group, Saga Prefecture, southwestern Japan. Bulletin of the Mizunami Fossil Museum, 33: 87-101.

Yasuhara, M., Irizuki, T., Yoshikawa, S. \& Nanayama, F. 2002. Changes in Holocene ostracode faunas and depositional environments in the Kitan Strait, southwestern Japan. Paleontological Research, 6: 85-99.

Van Den Bold, W.A. 1957. Ambocythere, a new genus of Ostracoda. Annals and Magazine of Natural History, Series 12, 10: 801-813.

Van Morkhoven, F.P.C.M. 1963. Post-Palaeozoic Ostracoda, Their Morphology, Taxonomy, and Economic Use, Volume II Generic Descriptions. Elsevier, New York, 478pp.

Wang, P. \& Zhao, Q. 1985. Ostracod distribution in bottom sediments of the East China Sea. In: Wang, P. (Ed.), Marine Micropaleontology of China. China Ocean Press, Beijing, 70-92.

Wang, P., Zhang, J., Zhao, Q., Min, Q., Brian, Y., Zheng, L., Cheng, X. \& Chen, R. 1988. Foraminifera and Ostracoda in Bottom Sediments of the East China Sea. Ocean Press, Beijing, 438pp.

Whatley, R.C., Siveter, D.J. \& Boomer, I.D. 1993. Arthropoda (Crustacea: Ostracoda). In: Benton, M.J. (Ed.), The Fossil Record 2. Chapman \& Hall, London, 343-356.

Zhao, Q. \& Wang, P. 1988. Distribution of modern Ostracoda in the shelf seas off China. In: Hanai, T., Ikeya, N. \& Ishizaki, K. (Eds), Evolutionary Biology of Ostracoda-Its Fundamentals and Applications. Kodansha, Tokyo, 805-821.

Zhao, Q., Wang, P. \& Zhang, Q. 1985. Ostracoda in bottom sediments of the South China Sea off Guangdong Province, China. In: Wang, P. (Ed.), Marine Micropaleontology of China. China Ocean Press, Beijing, 196-217.

Zheng, Z. 1994. A comprehensive ecological and palaeoecological study on the sedimentary organisms in the northern and eastern area of the South China Sea. Hubei Science and Technical Press, Beijing, 175pp.

Zhou, B. 1995. Recent ostracode fauna in the Pacific off Southwest Japan. Memoirs of the Faculty of Science, Kyoto University, Series of Geology \& Mineralogy, 57: 21-98. 